DOI: $10.15575 /$ ks.vi3. 9866

\title{
India-France Relations in the Post-Cold War Era
}

\author{
Debasish Nandy \\ Department of Political Science Kazi Nazrul University West Bengal, India \\ Corresponding Author Email: debasishnandy.kc@gmail.com
}

\begin{abstract}
It is not easy to carry out international cooperative relations especially after the cold war era, India is one of the countries that started to rebuild its country by conducting international cooperation, this study aims to analyze the very close cooperation relationship between India and France in several fields, such as diplomatic, cultural, educational, security, technology and even nuclear development are forms of cooperation between the two countries. So that later this research can be useful for countries that want to improve international cooperation relations. This study uses qualitative research with triangulation analysis techniques and content analysis which results in the nature of India-French relations in the postCold War era is almost amicable. Post-Cold War India-French relations are moving in the right direction in a multidimensional and multi-layered orientation.
\end{abstract}

Keywords: French, India, War, Postcold War

Tidaklah mudah untuk melakukan hubungan kerjasama internasional apalagi setelah era perang dingin, India merupakan salah satu negara yang mulai membangun kembali negaranya dengan melakukan kerjasama internasional, penelitian ini bertujuan untuk menganalisis sangat eratnya hubungan kerjasama antara India dan Perancis di beberapa negara. bidang-bidang, seperti diplomatik, budaya, pendidikan, keamanan, teknologi bahkan pengembangan nuklir merupakan bentuk kerjasama kedua negara. Sehingga nantinya penelitian ini dapat bermanfaat bagi negara-negara yang ingin meningkatkan hubungan kerjasama internasional. Penelitian ini menggunakan penelitian kualitatif dengan teknik analisis triangulasi dan analisis isi yang mengakibatkan sifat hubungan India-Prancis pasca Perang Dingin hampir bersahabat. Hubungan India-Prancis pasca-Perang Dingin bergerak ke arah yang benar dalam orientasi multidimensi dan multi-lapis.

Kata kunci: Perancis, India, Perang, Perang Dingin

\section{INTRODUCTION}

Countries like humans will not be able to live well without cooperation, since the era after the cold war, the recovery of the country has been the focus of the affected countries (Mingst \& Karns, 2019), including India. One of the efforts made by India to restore stability to the country is to open relations with other countries (Sandole, 2013).India-France relations in the post-Cold War era were very close. In 1980, relations between the two countries were getting stronger starting with the French who wanted to provide various forms of cooperative relations to be carried out with India. Relations between India and France have traditionally been close and friendly. With the establishment of the strategic partnership in 1998, there has been significant progress in all areas of bilateral cooperation through regular high-level exchanges at the Head of State / Head of Government level and increased cooperation and exchange including in special areas such as research cooperation beyond numbers, defense, education (Sheth, 1995).

Even France is a country that has collaborated with India in the field of civilian nuclear. In the postCold War era, India is facing many challenges. India is looking for a reliable Western partner to deal with common problems in the fields of international terrorism, global security, economic security and

\section{* Copyright (c) 2020 Debasish Nandy}

This work is licensed under a Creative Commons Attribution-ShareAlike 4.0 International License.

Received: 7 Oktober 2020; Revised: 4 November 2020; Accepted: 5 November 2020 
environmental disasters.Due to the same vision the relationship between the two countries is getting stronger and running well, many agreements have been made in the fields of trade, security, higher education and human contact. This research is interesting because it will discuss in depth the cooperation between the two countries (wikipedia, 2020).

As for previous research on Indian international relations such as research Mansingh (1994) on India and China relations, Chatterjee (2011) on India's international relations with China and the United States, Rekha (2017) on international relations between India and Russia and research by Ghosal (2016) calm international relations between India and Israel, there has been no research that specifically looks at the international relations between India and France, the aim of the study is to find out what forms of international relations between India and France after the cold war which will be useful in studies cooperation in India later.

This research is very interesting because France is one country that is very close compared to the others, the relationships are all going well which will be very interesting to discuss and be used as a reference for other research and can even be a reference for other countries that want to start. cooperation.

\section{RESEARCH METHOD}

This study uses a qualitative research method (Bengtsson, 2016), where the researcher describes each data obtained in the form of narratives, with triangulation techniques and data analysis (Triangulation, 2014). The researcher analyzes the data obtained through literature studies and searches for data in Indian government archives.

This study focuses on the collaborative relationship between India and France, where the detailed relationship between researchers is divided into several parts to make it easier for researchers and readers to understand this research. The division of cooperation studied is in the fields of Diplomatic, Economics, Strategic Engagement, Science and Technology, Nuclear Energy, Defense, Cultural, Educational and Tourism Linkages.

\section{RESULTS AND DISCUSSION}

\section{Diplomatic Ties}

Macron visits are believed to improve relations between the two countries. which is now for countries such as India and France to initiate an institutional narrative and become leaders. The arrival of the macron makes the India-France bilateral relationship bigger, and there are signs that the political leaders of both sides are exploiting it (Aliberti, 2018). India also has joined the United States, Australia and Japan as part of the "quad" initiative, a strong cooperative relationship between India and France that is growing and developing in the western Indian brothers. While China is starting to take advantage of India's geographic location in the Indian Ocean here India needs a strong partner such as France as a powerhouse in protecting its territories and France can continue to play its traditional role as a provider of national and regional security. On this view, cooperation to achieve the ultimate goal of an interoperative naval force that can use each other's naval facilities will inevitably result in a more effective security architecture in the India-Pacific.

The visit between the presidents has become a new determination for the two countries in forging a partnership, the visit of French president Francois Hollande in 2016 and President Macron afterwards, 
Khazanah Sosial, Vol. 2 No. 3: 125-132

India-France Relations in the Post-Cold War Era

Debasish Nandy

and vice versa Prime Minister Narendra Modi also visited France, this strong diplomatic relationship is what makes the relations between the two countries quite close and the cooperation is running smoothly.

After the Nukti Trial in 1998 France became the main venue and the first country to dialogue with India, as well as the imposition of bilateral sanctions on India France provided support and provided a broader understanding of India's security obligations than any other country. In addition, France also helped establish a website called Sriharikota (Mukherjee \& Biswas, 2005) and assisted in the development of hosting machines. After the Cold War France also decided that France's preferred partner in the Indian Ocean was India, which was stated in the 1998 strategic partnership agreement and the 2008 civilian nuclear agreement. The disintegration of the Soviet Union and subsequent liberalization reforms in India in the early 1990s opened new frontiers in view Indian foreign policy. The steady growth of the economy and the developing military modernization program should be recognized by the French establishment (Babar, 2019).

Important points in the French cooperation relations in the diplomatic field can be seen from 3 indicators, namely France supports India for a permanent seat on the UN security council, France supports India's membership in the Multilateral Export Control regime - NSG and MTCR and political cooperation begins with French support for India in limiting international sanctions on Delhi following the 1998 nuclear test.

\section{Economic Relations}

Due to India's confined economic policy India-France, trading relations could not grow during the Cold War period (S. Gupta, 2009). After opening-up, its market emphasizing the market economy in the early 1990s commercial linkages started to grow between the two. India's big and potential market and impressive growth of economy collectively abled to attract the various investors of France to invest in India. Bilateral trading relations increased gradually, but it is not satisfactory. France is the 9th largest investor in India. Foreign Direct Investment (FDI) flows from France to India is very impressive. France is the ninth-largest foreign investor in India. France government and various MNCs have invested a good amount of money in India. Around 1000 French companies started business in India. Around 150 Indian companies have invested in France. French companies like Capgemini, Schneider Electric, Lafarge, Renault, Sanofi Aventis, Essilor, BNP Paribas, Louis Dreyfus, Armateurs, Alstom, Areva, Saint-Gobain, Onyx, Pernod Ricard, Alcatel-Lucent, Louis Vuitton, L'Oreal, GDF, Total, Danone, Air Liquide, Vici, Veolia, Vicat, etc. France companies have invested in various sectors like Chemicals, Cement and Gypsum Products, Services Sector, Fuels, Electrical Equipment, and automobile sector.

In terms of the economy, when viewed from April 2018 to March 2019, the economic relations between the two countries reached USD 11.89 billion, of which India's exports to France reached USD 5.23 billion, an increase of $6.78 \%$. and French exports to India increased $2.17 \%$ in the same period to USD 6.66 billion. It's just that if the total overall trade relationship is still low, trade between India and France is only up to $1.41 \%$ of the international trade that is carried out (Embassy of India, 2020).

Both India and France have important bilateral investment and trade and commercial cooperation. The Joint Economic Committee exists at the Minister of Trade level from both sides. To increase bilateral trade several joint working groups have been formed in various fields, such as Information \& Telecommunication Technology, Road Development, Sustainable Urban Development, Agriculture and Food Processing, Mineral Exploration and Development, Energy, etc. 
Khazanah Sosial, Vol. 2 No. 3: 125-132

India-France Relations in the Post-Cold War Era

Debasish Nandy

\section{Strategic Engagement}

In the post-Cold War era, the entire has to face several new unconventional security challenges like a nuclear race among the states, terrorism, religious extremism, trafficking, growth of sea piracy, ethnic conflict, risk of biochemical weapons, pandemic daises like HIV, Ebola, COVID-19, etc. These are posed a serious threat to all countries. To chase against the evil forces, joint actions are necessary. The nature strategy of a state is now multi-dimensional and collaborative. This can be called 'strategic interdependency'. India and France have made an inter-dependent strategic partnership. Both countries started joint naval exercises 'Varuna' in 1983. As the bilateral naval exercise, the 'Varuna 2019' held in two phases. The first phase was held in Goa and the second part of 'Varuna 19' held at the end of May in Djibouti, France (Scott, 2019).

Security cooperation is one of the issues of cooperation between the two countries in dealing with terrorists, starting with a naval exercise in 1983 called "Varuna" in 2001, this is a form of strategic cooperation between the two countries. growing together in the old complexity, this exercise can illustrate the close relationship between the two countries, which is in line with the vision of the two countries which was ratified by the signing between the two President Emmanuel Macron and Prime Minister Narendra Modi on a fresh visit in March 2018.This exercise was carried out with the intention of developing interoperability between the two naval forces and encouraging cooperation by way of direct practice together for a long time. which this exercise also aims to promote maritime security activities and demonstrate the same commitment and interests between the two countries.

France's early resistance to decolonization and its encampment with the US-led military alliances were in contradiction to India's anti-imperialist and Non-Alignment policies. India's preoccupation with its inward-looking domestic political economy offered little common ground for Paris to engage with New Delhi (A. Gupta, 2016). France is very much aware of the security challenges in the South Asian region and the growing Chinese influence in the India-Pacific region. France's wider security interests in the region, especially terrorism, and maritime security concerns in the Indian Ocean Region (IOR) also call for enhanced cooperation with India(Swati,2017:137). France has been one of the key partners of India's defense and security. France has been one of the major technology providers and joint defense equipment manufacturers of India. In the field of defense, the India-France relation is a buyer-seller in nature.

The geopolitical interests of France in South Asia are very much vested due to secure its sea-based trade routes in the Indian Ocean. India is the largest arms importer of the world during the period 20122016 (Times, 2017). The hard reality is that France is considering India as a very good client for selling arms and defense-equipment. India aims to be a global power insisting he strengthens its national security. As a part of it, India is purchasing more arms from France. This is one of the cases of the growing synergies between New Delhi and Paris. In 1998, the two countries had initiated 'Strategic Dialogue' for the convergence of their strategic perceptions. Strategically, India and France have made close ties. For France, "European Strategic Autonomy" is a continuation of its own concept of "National Strategic Autonomy" and this should be familiar to parts of India because India also applies a similar system (Petersen, 2019). It is also true that France did not fulfill all defense-related demands made by India. For Instance, French manufacturer would not stand for India's request to have over 100 of the 126 fighters constructed by Hindustan Aeronautics Limited (HAL) in India.

The main ongoing bilateral defense-related projects are as follows: Intergovernmental agreement for India's unsuccessful purchase of 36 Rafale jets in New Delhi on 23 September 2016 by India and France, Contract for six Scorpion submarines from M / s DCNS signed in October 2006, Multi-role and twin-engine fighters will meet important shortcomings in the armament of the Indian Air Force (IAF), New Delhi plans 
to use the fighter as part of the "strategic air delivery system" for nuclear weapons and IAF also inducted the first domestically developed Tejas Light Combat Aircraft (LCA) earlier this year and a single-engine light fighter intended to replace the MiG-21 fleet.

India is looking for strategic space in the India-Pacific region. There is great potential in IndiaFrench collaboration in the Indian Ocean. While India is engaging the US, Japan and Australia as part of the "Quad" initiative, close bilateral partnerships with France are developing in the region, particularly in the western Indian Ocean.

\section{Cooperation in Science and Technology}

In the field of science and technology field, New Delhi and Paris did a lot of works together. Mainly. India and France science and technology cooperation based on 'space science'. India's relations with France in space science had commenced in 1964, based on French technological support. Since then, France has provided technical assistance to India for building and developing India's Space Research Centre. Until now, around fifty French technology-based indigenous rockets have been launched from the Thumba Equational Rocket Launching Station (TERLS) that has contributed significantly to the foundational development of India's space programme (Lele, 2015). In 1972, the India-French Joint Commission for Space Research was established by ISRO to conduct a joint research programme for manufacturing satellites and satellite launcher vehicles. France has always been an important partner in the development of advanced technologies.

The major areas of cooperation in the field of science and technology are as follows-

1. India and France issued a "Joint Vision for Space Cooperation" during the visit of President Macron to India (March 2018) to establish a historic bonding in space science.

2. The two sides have jointly developed the Megha-Tropiques satellite providing valuable scientific data. ISRO and France Space Research Centre had launched a satellite-GSAT-11 in December 2018 from France.

3. The two countries are also cooperating in the training of medical support personnel for Indian astronauts, who will be part of India's manned space mission by 2022.

4. An Implementing Arrangement between ISRO and CNES France for Joint Maritime Domain Awareness was also signed during this visit. France is cooperating with ISRO for the last fifty years. The French Space Agency is conducting a joint research project with ISRO.

5. In 2015, Indian Prime Minister Modi and French President Francois Hollande has made a roadmap of new space project- Planetary Mars Orbiter Mission(MOM).

\section{Nuclear Energy Cooperation}

To ensure its energy security both countries have concluded several agreements. Civil nuclear cooperation for generating electricity is a very significant step towards mitigating the energy crisis of India. Nuclear Energy cooperation is another key issue of India-France bilateral relations. The civil nuclear cooperation between India and France got started in the early 1980s due to the stop of American fuel and technological supply to India's nuclear power plants. After Pokhran-I in 1974, the USA cut its supply chain. Following the American standpoint, other Western countries were also uninterested to help India to get a bailout from this situation. France agreed to do a collaboration with India in civil nuclear energy. Since then, France started to supply uranium fuel to India's first nuclear power plant.

An agreement on civil nuclear cooperation was signed between India and France on 30 September 2008 during the visit of then Prime Minister of India to France. India is not a signatory of NPT and CTBT. 
The USA, Russia, UK, China, and other countries took a strong standpoint against India for not signing on non-proliferation treaties. But, France had a softening attitude towards looking to India's responsible nuclear research and use. France was very much supportive of the 'India-US Civil Nuclear Deal' (Sharma, 2005). France is also very much supportive of India's accession in NSG and Missile Technology Control Regime(MTCR). In 2010, France had agreed to set up two European Pressurised Reactors of 1665 MW each at Jaitapur, India. Some environmental issues raised in the construction of the nuclear breeders. However, the projects are smoothly going on. Under that framework, the French utility company EDF and NPCIL signed a (revised) MoU on 22 March 2016 for the construction of six EPR units at Jaitapur of 1650 MWe each.

\section{In Defence of International Terrorism}

India and France are determined to eliminate terrorism from the globe. Several joint initiatives have been taken by the two countries. After the 9/11 incident both India and France had agreed to fight against global terrorism collectively. Al Qaida and the Taliban were the deadliest terrorist groups in South Asia. Since 2014, ISI or IS has been the most dangerous terrorist group in the world. Through their networks with the help of their sister's concerns, they operated several terrorist attacks in Europe. France was also vehemently attacked. As per the data of the Institute for Economics and Peace, USA, the number of countries experiencing a terrorist attack in 2015 was one less than in 2014, with 92 countries recording an attack in 2015. This makes 2015 the first year to see a decrease in the number of countries attacked since 2010 and could highlight a changing trend (Index, 2015), In the face of terrorist crimes that are increasingly angry India and France will hold the 14th meeting which aims to establish a joint working group against terrorism in India in February. Each country in sending their confidants from India is led by Mahaveer, a joint secretary for counter terrorism at the Foreign Ministry, while France is led by David Bertolotti, an assistant minister of foreign affairs for strategic security and disarmament at the French and European Ministries of Foreign Affairs. both of which agree to jointly strengthen the security against terrorism, which forms the basis of the strategic partnership between the two countries. As part of this initiative, India and France conducted joint counter-terrorism exercises under 'Exercise Shakti-2019' at the Mahajan shooting range in Rajasthan from 31 October to 13 November 2019.

\section{Cultural, Educational and Tourism Linkages}

Both India and France are culturally rich. Both are fond of art, culture, music, and creativity. Indian culture is very popular among the French people. Indian Council for Cultural Relations (ICCR) regularly send cultural troops to France to perform various cultural events. enjoys wide admiration among the people of France. Private troops and individual artists, singers, dancers, actors, and actresses are used to go to France on various occasions. Some occasions are organized by Indian communities in France. ICCR regularly sends Indian cultural troupes to France. Indian Government has decided to open a cultural center in Paris to popularize Indian culture in French society. An Indian Cultural Centre is proposed to be opened in Paris. On the honor of the visit of President Hollande to India in January 2016, ICCR presented the 'Namaste France'Cultural Festival in France from 15 September to 30 November 2016. The Embassy of France, New Delhi also organized a French cultural festival 'Bonjour India' in India from November 2017 to February 2018. The Ministry of External Affairs (MEA) had organized a Regional Hindi Conference at Inalco University, Paris from 14-16 September 2016.

To promote bilateral cooperation in the field of Science and Technology, the India-French Centre for the Promotion of Advance Research (CEFIPRA) was formed in New Delhi in 1987. Joint research 
Khazanah Sosial, Vol. 2 No. 3: 125-132

India-France Relations in the Post-Cold War Era

Debasish Nandy

projects have conducted this Centre on various serious innovation for mankind. Based on Joint IndiaFrench research projects several patents have been achieved. India has been the 'Country of Honour' for the 2020 edition of Livre Paris, the Paris international book fair. India will organize Namasté France again in 2021-2022. To promote Indian culture and Philosophy in France Vivekananda Cultural Centre, Paris has taken so many initiatives.

The twenty-first century is the century of knowledge. Following Foucault's famous line, 'knowledge is power' it is quite natural to enhance bilateral knowledge exchange programmes through education and technology. India and France have expanded educational cooperation in the field of science and technology, literature, management, business and finance, social sciences. Around 10000 Indian students are studying in France. Several leading universities and institutions of India are offering French language courses. During the visit of Prime Minister Modi to France in April 2015, the two sides decided to facilitate the professional experience for their students in both countries after the completion of their academic courses. Around 109,000 Indian community living in France. They are felicitating Indian history, heritage, Philosophy, and culture in France. There are more than 50 Indian community organizations active in France. Major communities constituting the Indian origin population originate from Puducherry and Tamil Nadu, Gujarat, and Punjab. The International Day of Yoga has been organized by the Embassy of India, Paris. Indian community and Indian Embassy of France has celebrated the 150th birth anniversary of Gandhi Ji. In 2018, 700000 Indian tourists visited France, 17 \% more than in 2017 and more than 250,000 French tourists visited India. Several tours and travel companies in India are conducting the package tour in Europe. Through tourism people to people, contact is not only enhancing, but both sides are also being economically benefiting.

\section{CONCLUSION}

The nature of India-France Relations in the post-Cold War era is almost cordial. In the post-Cold War India-France relations go in the right direction with multi-dimensional and multi-layered orientations. In the economic sector, so many positive steps have been taken by the two governments. Since the early 1990s, French business houses and enterprises have started to make strong linkages with the Indian economy and industry looking to India's rapid economic growth and potential market. Bilateral cultural and educational linkages are also immensely helped India in growing people-to-people contacts Diplomatically, India has been supported by France on many issues. Indian Constitution has borrowed so many ideas from the French Constitution. The democratic values and liberal approach of the two countries create an opportunity to share a common standpoint in world politics.

France is very much supportive of India's desire for accession to the NSG. India and France have taken so many decisions regarding climate change and global warming. India and France have consistently condemned terrorism and have resolved to work together for the adoption of the Comprehensive Convention on International Terrorism (CCIT) in the UN. After the Pulwama attacks, France had condemned Pakistan and supported India's immediate action. France also agreed with India to take punitive measures against the Pakistan-based 'global terrorist' Hafiz Saeed. Its, true on some issues both differed to each other, yet, it can be said New Delhi-Paris relations is less ambiguous in comparison to others. 


\section{REFERENCES}

Aliberti, M. (2018). Cooperation and Competition in India's Space Relations. In India in Space: Between Utility and Geopolitics (pp. 195-240). Springer.

Babar, S. I. (2019). India's Military Modernization: Implications for Strategic Stability in South Asia. Quaid-i-Azam University, Islamabad.

Bengtsson, M. (2016). How to plan and perform a qualitative study using content analysis. NursingPlus Open, 2, 8-14.

Chatterjee, A. (2011). India-China-United States: the post-Cold War evolution of a strategic triangle. Political Perspectives, 5(3), 74-95.

Embassy of India. (2020). Brief on India-France Bilateral Relations. Embassy of India, Paris. https://www.eoiparis.gov.in/page/bilateral-brief/

Ghosal, D. (2016). Strategic hyphenation between India and Israel: The major areas of cooperation and constraints in the Post-Cold War Era. Jadavpur Journal of International Relations, 20(1), 65-101.

Gupta, A. (2016). Australia and Strategic Stability in Asia. In Strategic Stability in Asia (pp. 151-168). Routledge.

Gupta, S. (2009). INDO-FRENCH RELATIONS IN THE POST-COLD WAR PERIOD: TRANSFORMATION FROM COMMERCIAL TO STRATEGIC PARTNERSHIP. The Indian Journal of Political Science, 1179-1199.

Index, G. T. (2015). Measuring and understanding the impact of terrorism. Institute for Economics and Peace, 13-14.

Lele, A. (2015). Space Collaboration between India and France: Towards a New Era. Institut Francais des Relations Internationales (IFRI).

Mansingh, S. (1994). India-China relations in the post-Cold War era. Asian Survey, 34(3), 285-300.

Mingst, K., \& Karns, M. P. (2019). The United Nations in the post-cold war era. Routledge.

Mukherjee, A., \& Biswas, A. (2005). E-Governance in India. EuroIMSA, 429-433.

Rekha, C. (2017). India-Russia Post Cold War Relations: A New Epoch of Cooperation. Taylor \& Francis.

Sandole, D. J. D. (2013). Capturing the complexity of conflict: dealing with violent ethnic conflicts of the post-cold war era. Routledge.

Scott, D. (2019). France's "Indo-Pacific" Strategy: Regional Projection. Journal of Military and Strategic Studies, 19(4).

Sharma, D. (2005). India's Nuclear Estate. Philosophy and Social Action, 31(4), V.

Sheth, D. L. (1995). Democracy and globalization in India: post-cold war discourse. The Annals of the American Academy of Political and Social Science, 540(1), 24-39.

Times, H. (2017). India is World's largest Arms Importer. Hindustan Times. https://www.thehindu.com/news/national/india-is-worlds-second-largest-armsimporter/article26502417.ece

Triangulation, D. S. (2014). The use of triangulation in qualitative research. Oncology Nursing Forum, 41(5), 545.

wikipedia. (2020). india-france. Wikipedia. https://en.wikipedia.org/wiki/France-India_relations 